\title{
Rapid and Reversible Secretion Changes during Uncoupling of Rat Insulin-producing Cells
}

P. Meda, D. Bosco, M. Chanson, E. Giordano, L. Vallar, ${ }^{\star}$ C. Wollheim, ${ }^{\star}$ and L. Orci

Department of Morphology and *Institute of Clinical Biochemistry, University of Geneva Medical School, CH-1211 Geneva, Switzerland

\begin{abstract}
To determine whether insulin secretion is affected by a blockage of gap junctions between $B$ cells, we have studied the secretion of rat pancreatic islets of Langerhans, primary dispersed islet cells, and cells of the RINm5F line, during shortterm exposure to heptanol. Within minutes, this alkanol blocked gap junctions between the $B$ cells of intact islets and abolished their normal secretory response to glucose. These two changes were rapidly and fully reversible after return of the islets to control medium. We further found that heptanol had no significant effect on the glucose-stimulated secretion of single B cells but inhibited that of B cell pairs. In the clone of RINm5F cells, whose junctional coupling and D-glyceraldehyde-induced stimulation of insulin release by aggregated cells were also inhibited by heptanol, this alkanol did not perturb intracellular pH and $\mathrm{Ca}^{2+}$ and the most distal steps of the secretion pathway. In summary, a gap junction blocker affected the secretion of insulin-producing cells by a mechanism which is dependent on cell contact and is not associated with detectable pleiotropic perturbations of the cell secretory machinery. The data provide evidence for the involvement of junctional coupling in the control of insulin secretion. (J. Clin. Invest. 1990. 86:759-768.) Key words: B cells $\bullet$ calcium $•$ gap junctions • pancreatic islets • reverse hemolytic plaque assay
\end{abstract}

\section{Introduction}

The B cells of the endocrine pancreas are connected by gap junctions (1), the membrane specializations thought to provide channels for direct cell-to-cell communications, i.e., for the cytoplasm-to-cytoplasm exchange of ions and molecules of $<\sim 900$ daltons $(2,3)$. Two lines of evidence indicate that these communications, an event also referred to as junctional coupling, may participate in the control of insulin secretion. First, gap junctions and coupling increase between $B$ cells during sustained stimulation of insulin secretion $(4,5)$. Secondly, isolated (uncoupled) B cells show impaired secretion that is corrected, at least partially, after reaggregation and reestablishment of gap junctions $(4,6)$.

As yet, however, the critical evidence that changes in insulin secretion occur during a rapid and reversible modulation of gap junction permeability has not been provided. To address

Address reprint requests to Dr. Meda, Department of Morphology, University of Geneva, C.M.U., 1, rue Michel Servet, CH-1211 Geneva 4, Switzerland.

Received for publication 22 February 1988 and in revised form 20 February 1990.

J. Clin. Invest.

(c) The American Society for Clinical Investigation, Inc.

$0021-9738 / 90 / 09 / 0759 / 10 \$ 2.00$

Volume 86, September 1990, 759-768 this question, we have studied now the secretion of single (uncoupled) and clustered insulin-producing cells during shortterm incubations in the presence of a long-chain alcohol that blocks junctional communications (7).

\section{Methods}

Preparation of islets of Langerhans and insulin-producing cells. Intact islets of Langerhans were isolated by enzymatic digestion and Ficoll purification from the splenic pancreas of adult (250-350 $\mathrm{g}$ body wt) male Sprague-Dawley rats (8).

To prepare primary cells, isolated islets were first incubated for 15 min at room temperature in a $\mathrm{Ca}^{2+}$-free Krebs-Ringer buffer bicarbonate (KRB) and then dispersed by repeated aspiration through a series of syringe needles, as described in Salomon and Meda (8). After a 3-min incubation in a spinner flask containing a $\mathrm{Ca}^{2+}$-free medium supplemented with $0.1 \%$ trypsin (1:250; Difco Laboratories, Inc., Detroit, MI), the cells were centrifuged in sterile RPMI1640 medium (Gibco Laboratories, Grand Island, NY) supplemented with $10 \%$ fetal calf serum, plated on bacteriological culture dishes, and kept overnight at $37^{\circ} \mathrm{C}$ in a air $/ \mathrm{CO}_{2}$ incubator $(8)$.

RIN cells (9) were obtained by mild trypsinization of cultures of the $\mathrm{m} 5 \mathrm{~F}$ clone (10) that were passaged once every $5 \mathrm{~d}$ and also subcultured on RPMI 1640 medium supplemented with $10 \%$ fetal calf serum.

Dye coupling studies. Junctional coupling of primary B cells was determined by injecting Lucifer Yellow into individual cells located deeply within the isolated islets $(11,12)$. Injections were performed on the heated $\left(37^{\circ} \mathrm{C}\right)$ stage of a UEM microscope (Carl Zeiss, Inc., Oberkochen, FRG) using glass electrodes $(\simeq 150 \mathrm{M} \Omega)$ that were filled with a $4 \%$ solution of Lucifer yellow in $1 \mathrm{M}$ lithium chloride, buffered to $\mathrm{pH}$ 7.2 with $10 \mathrm{mM}$ Hepes. The tracer was injected iontophoretically and under continuous electrophysiological control, as reported $(13,14)$. At the end of each injection, the islets were photographed and then fixed in $4 \%$ paraformaldehyde in phosphate-buffered saline for subsequent embedding in Epon and serial sectioning $(11,12)$. Evaluation of coupling was restricted to $B$ cells that were identified by immunostaining with an antiinsulin serum and/or by their location in the deep regions of the islets $(11,12)$. Coupling extent was evaluated by measuring the area of Lucifer yellow diffusion on photographs of the intact islets (11, 13) and by scoring the number of $B$ cells labeled by the tracer on sections that were cut serially throughout the microinjected islets $(11,12)$.

Junctional coupling of RINm5F cells (passages 107-110) was determined in a similar manner by injecting individual cells within monolayer clusters of 3-4-d-old cultures. For these experiments, 2.5 $\times 10^{4}$ cells per $\mathrm{ml}$ were plated initially. The number of cells labeled by Lucifer yellow was determined on photographs of the intact clusters, which were taken immediately after each injection.

Insulin secretion studies. For measurement of insulin secretion, batches of 10 freshly isolated islets were preincubated $15 \mathrm{~min}$ at $37^{\circ} \mathrm{C}$ in KRB containing $12.5 \mathrm{mM}$ Hepes, $0.5 \%$ bovine serum albumin, and $2.8 \mathrm{mM}$ glucose (control KRB) and, then, incubated in $1 \mathrm{ml}$ of control KRB, supplemented or not with the different secretagogues $(16.7 \mathrm{mM}$ glucose and $1 \mathrm{mM}$ 3-isobutyl-1-methyl-xanthine [IBMX] ${ }^{1}$ ) and uncoupling agent (0.5-3.5 mM heptanol) to be tested. Heptanol was

1. Abbreviations used in this paper: IBMX, 3-isobutyl-1-methylxanthine 


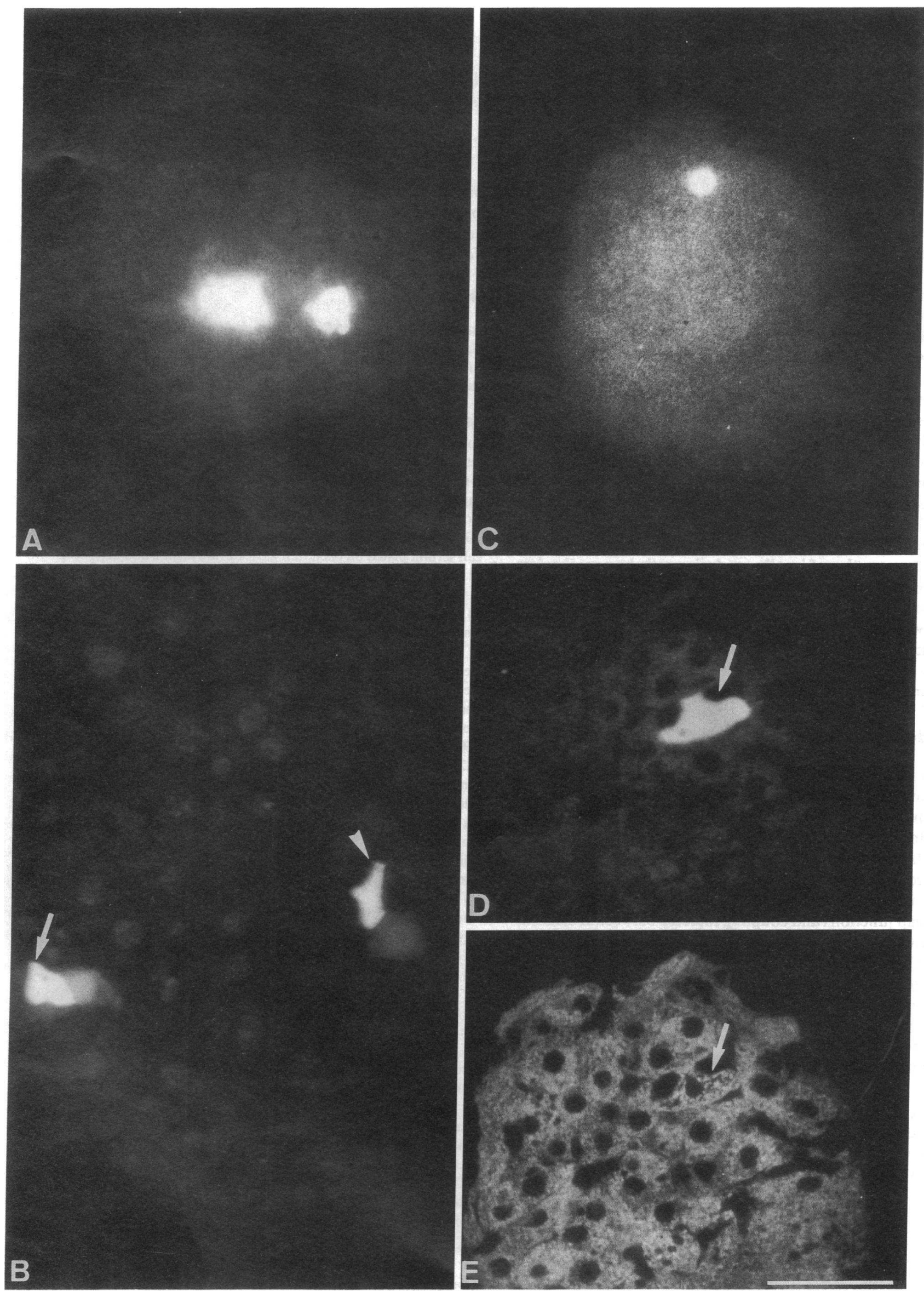

760 Meda, Bosco, Chanson, Giordano, Vallar, Wollheim, and Orci 
added directly to the medium in which it was mixed by a 3-min sonication. At the end of the 15 -min incubation at $37^{\circ} \mathrm{C}$, aliquots of the medium were removed and rapidly frozen for measurement of secreted insulin. The islets were then thoroughly rinsed in control $\mathrm{KRB}$, extracted for $24 \mathrm{~h}$ at $4^{\circ} \mathrm{C}$ in $1 \mathrm{ml}$ of acid-ethanol and the extract was stored frozen to assess insulin content. To assess the reversibility of the heptanol effects, the islets were first incubated in the presence of the alcohol as just described, then rinsed repeatedly, and finally incubated again in a test medium devoid of heptanol for $15 \mathrm{~min}$. Immunoreactive insulin of media and extracts was measured using a radioimmunoassay with a charcoal separation step. Values of secreted insulin were expressed both as absolute insulin concentrations and as percentage of the initial insulin content of the B cells $(6,11)$.

The insulin secretion of primary dispersed islet cells was studied using a reverse hemolytic plaque assay. To this end, the cells were mixed with $4 \%$ (vol/vol) packed sheep red blood cells coated with protein A and introduced with control KRB into poly-L-lysine-coated glass chambers, as described (8). After cell attachment, each chamber was thoroughly rinsed and then filled with control KRB supplemented with a heat-inactivated polyclonal antibody against insulin (Dr. P. H. Wright, Indiana University School of Medicine, Indianapolis, IN) diluted 1:50, and containing either 2.8 or $16.7 \mathrm{mM}$ glucose with or without $0.5 \mathrm{mM}$ heptanol. After a 30 -min incubation at $37^{\circ} \mathrm{C}$, the chambers were rinsed, filled with control KRB supplemented with 1:10 guinea pig complement (Behring Institut, Marburg, FRG), and incubated $60 \mathrm{~min}$ at $37^{\circ} \mathrm{C}$. The chambers were then filled with a $0.2 \%$ solution of trypan blue and incubated for $10 \mathrm{~min}$ at $37^{\circ} \mathrm{C}$. At the end of this last incubation, they were rinsed again and finally fixed in Bouin's solution (8). Insulin-containing B cells were identified by immunostaining with the same antibodies used for the secretion test, now diluted 1:200, as described $(8,15)$. Six experiments (100-200 insulinimmunostained and trypan blue-negative single $B$ cells and $B$ cell pairs were scored per condition and per experiment) were performed to evaluate the percentage of $B$ cells that formed a hemolytic plaque and the individual areas of all these plaques, two parameters that indicate the proportion of secreting cells and give a relative estimate of their individual output, respectively $(8,15-17)$. From these data, we calculated the total plaque development per $B$ cell aggregate and the average total plaque development per $B$ cell, as described in $(8,15)$. Values and mean \pm SEM estimates were compared by analysis of variance and by a Student's unpaired $t$ test, respectively.

To test the secretion of single RINm5F cells, freshly passaged cells were diluted at a density of $2 \times 10^{5} / \mathrm{ml}$ and kept at $37^{\circ} \mathrm{C}$ under continuous rotation within a spinner flask, which was filled with RPMI 1640 medium supplemented with $25 \mathrm{mM}$ Hepes and $1 \%$ newborn calf serum. Under these conditions, virtually all cells were still single and excluded trypan blue $3 \mathrm{~h}$ after cell passage. At this time, aliquots of 500,000 single RINm5F cells were prepared into siliconized tubes for the test incubation. To test the secretion of aggregated RINm5F cells, 150,000 cells were plated per $35-\mathrm{mm}$ culture dish $(2 \mathrm{ml}$ of medium) and cultured for $5 \mathrm{~d}$. At this time, most cells had formed extensive aggregates and were used for the secretion test. To this end, both single and aggregated cell aliquots were incubated $30 \mathrm{~min}$ at $37^{\circ} \mathrm{C}$ into $2 \mathrm{ml}$ of control KRB, supplemented or not with $10 \mathrm{mM}$ D-glyceraldehyde and $3.5 \mathrm{mM}$ heptanol. Media and cells were collected for insulin measurement as described above. Radioimmunoassay for insulin and expression of data were also as described for intact islets of Langerhans.

To study the distal steps of the secretory pathway, single RIN cells were permeabilized by 10 pulses of $30 \mu \mathrm{s}$ of a $3 \mathrm{kV} / \mathrm{cm}$ electric field, as
Table I. Extent of Coupling between Insulin-producing B Cells

\begin{tabular}{|c|c|c|c|}
\hline Group & $\begin{array}{l}\text { Extent of dye } \\
\text { diffusion** }\end{array}$ & $\begin{array}{l}\text { Dye-labeled } \\
\text { B cells }{ }^{\ddagger}\end{array}$ & $\begin{array}{l}\text { Uncoupled } \\
\text { B cells }\end{array}$ \\
\hline & $\mu m^{2}$ & $n$ & $\%$ \\
\hline Control & $\begin{array}{c}527 \pm 23 \\
(64)\end{array}$ & $\begin{array}{c}3.0 \pm 0.4 \\
(20)\end{array}$ & 20 \\
\hline Heptanol $3.5 \mathrm{mM}$ & $\begin{array}{c}330 \pm 26^{8} \\
(56)\end{array}$ & $\begin{array}{c}1.5 \pm 0.2^{\S} \\
(25)\end{array}$ & 68 \\
\hline Heptanol reversibility & $\begin{array}{c}480 \pm 21^{\prime \prime} \\
(88)\end{array}$ & $\begin{array}{c}2.9 \pm 0.3^{\prime \prime} \\
(30)\end{array}$ & 30 \\
\hline
\end{tabular}

Values are mean \pm SEM and were compared using the unpaired Student's $t$ test. The number of *islets that were microinjected and of tinjected islets that were sectioned is indicated in parentheses. ${ }^{\S} P$ $<0.001$ as compared with the corresponding control group; " $P$

$<0.001$ as compared with the heptanol group.

described in (10). After permeabilization, $10^{6}$ cells were diluted in $1 \mathrm{ml}$ of a $140 \mathrm{mM}$ potassium glutamate buffer, supplemented with the different $\mathrm{Ca}^{2+}$ concentrations specified in the text, and tested for insulin secretion as described (10).

Measurement of cytosolic $\left[\mathrm{Ca}^{2+}\right]$ and $\mathrm{pH}$. Suspensions of RIN cells were loaded for $30 \mathrm{~min}$ at $37^{\circ} \mathrm{C}$ with $1 \mathrm{mM}$ fura-2/acetoxymethylester or $10 \mu \mathrm{M} 2^{\prime}, 7^{\prime}$-bis (carboxyethyl)-5,6-carboxyfluorescein/acetoxymethylester (BCECF), respectively. After washing, $10^{6}$ cells were suspended in $1 \mathrm{ml}$ of control KRB and placed in the glass cuvette of an LS3 spectrofluorometer (Perkin-Elmer Corp., Norwalk, CT) under continuous stirring at $37^{\circ} \mathrm{C}$. Measurements and calibrations were performed as previously described $(13,18)$.

\section{Results}

$B$ cell coupling. Fig. 1 shows the appearance of pancreatic rat islets microinjected with Lucifer yellow in their core, a region formed almost exclusively by insulin-producing B cells. In control islets, most microinjections led to the intercellular exchange of Lucifer yellow, indicating the frequent coupling of B cells (Fig. 1, $A$ and $B$ ). Characteristically, coupling was spatially restricted, the average number of communicating $B$ cells being $3.4 \pm 0.2$ for the 46 injections (all experimental groups pooled) that revealed coupling in this study. By contrast, in islets incubated in the presence of heptanol, most injections led to the retention of Lucifer yellow within the injected cell, indicating uncoupling (Fig. 1, $C$ and $D$ ) of the insulin-containing B cells (Fig. $1 E$ ). This uncoupling was confirmed by a quantitative analysis in control and heptanol-exposed islets. As shown in Table I, heptanol significantly $(P<0.001)$ decreased the extent of dye diffusion and the number of $B$ cells labeled by the dye after each injection. The alcohol also markedly increased the proportion of B cells that appeared uncoupled, as judged by their inability to exchange Lucifer yellow

Figure 1. Islets of Langerhans microinjected with Lucifer yellow. $(A)$ Two successive injections in a control islet reveal the intercellular diffusion of the injected tracer within limited areas of the islet profile. $(B)$ The corresponding section, through these two small areas, shows that Lucifer yellow had diffused into three coupled B cells in one communication territory (arrow) and into two B cells in the other (arrowhead). In the two territories, the arrow and the arrowhead point to the injected cell. $(C)$ After exposure to $3.5 \mathrm{mM}$ heptanol, microinjection failed to reveal intercellular diffusion of Lucifer yellow. (D) Accordingly, only the injected cell (arrow) was found labeled by the tracer in the corresponding section. (E) This uncoupled islet cell (arrow) was identified as an insulin-containing B cell by immunostaining. Bar, $50 \mu \mathrm{m}$ in $A$ and $C$ and $18 \mu \mathrm{m}$ in $\mathrm{B}, \mathrm{D}$, and $\mathrm{E}$. 
Table II. Insulin Secretion from Isolated Islets of Langerhans

\begin{tabular}{|c|c|c|c|c|}
\hline \multirow[b]{2}{*}{ Incubation } & \multirow[b]{2}{*}{ Group } & \multicolumn{3}{|c|}{ Secreted immunoreactive insulin } \\
\hline & & Control & $\begin{array}{l}\text { Heptanol } \\
3.5 \mathrm{mM}\end{array}$ & $\begin{array}{c}\text { Heptanol } \\
0.5 \mathrm{mM}\end{array}$ \\
\hline & & \multicolumn{3}{|c|}{ ng/l0 islets per $15 \mathrm{~min}$} \\
\hline 1st & Glucose $2.8 \mathrm{mM}$ & $\begin{array}{c}13.1 \pm 1.3 \\
(29)\end{array}$ & $\begin{array}{c}30.3 \pm 3.6^{\S} \\
(25)\end{array}$ & $\begin{array}{l}15.2 \pm 2.1 \\
(15)\end{array}$ \\
\hline 1 st & Glucose $16.7 \mathrm{mM}$ & $\begin{array}{l}40.2 \pm 2.9^{*} \\
\quad(28)\end{array}$ & $\begin{array}{c}28.7 \pm 4.6^{\S} \\
(24)\end{array}$ & $\begin{array}{c}29.5 \pm 3.0 \\
(15)\end{array}$ \\
\hline 1 st & $\begin{array}{r}\text { Glucose } 16.7 \mathrm{mM} \\
+ \text { IBMX } 1 \mathrm{mM}\end{array}$ & $\begin{array}{l}90.6 \pm 8.9^{* \ddagger} \\
(30)\end{array}$ & $\begin{array}{c}39.7 \pm 6.0 \\
(23)\end{array}$ & $\begin{array}{l}39.9 \pm 2.9 \\
(15)\end{array}$ \\
\hline 2nd & $\begin{array}{l}\text { Glucose } 2.8 \mathrm{mM} \\
\text { reversibility }\end{array}$ & $\begin{array}{l}5.4 \pm 0.5^{* *} \\
(10)\end{array}$ & $\begin{array}{l}6.3 \pm 0.7^{\ddagger \ddagger} \\
(10)\end{array}$ & ND \\
\hline 2nd & $\begin{array}{l}\text { Glucose } 16.7 \mathrm{mM} \\
\text { reversibility }\end{array}$ & $\begin{array}{c}26.6 \pm 2.5^{9} \\
(10)\end{array}$ & $\begin{array}{c}36.6 \pm 4.9 \\
\quad(10)\end{array}$ & ND \\
\hline 2nd & $\begin{array}{c}\text { Glucose } 16.7 \mathrm{mM} \\
+ \text { IBMX } 1 \mathrm{mM} \\
\text { reversibility }\end{array}$ & $\begin{array}{l}53.8 \pm 6.6^{\| \prime} \\
(10)\end{array}$ & $\begin{array}{c}56.7 \pm 5.3^{11} \\
(10)\end{array}$ & ND \\
\hline
\end{tabular}

During the first 15-min incubation, islets incubated in the presence of $2.8 \mathrm{mM}$ glucose, $16.7 \mathrm{mM}$ glucose, or $16.7 \mathrm{mM}$ glucose plus 1 mM IBMX (control groups), were compared with islets incubated in the corresponding medium, supplemented now with either 3.5 or 0.5 $\mathrm{mM}$ heptanol (heptanol groups). When the media were collected for measurement of the immunoreactive insulin secreted during the first incubation, heptanol was removed from all tubes, the islets were rapidly washed in control medium and tested again during a second 15min incubation in the absence (glucose $2.8 \mathrm{mM}$ group) or presence of secretagogues (16.7 mM glucose and $16.7 \mathrm{mM}$ glucose plus $1 \mathrm{mM}$ IBMX groups). Thus, during this second secretion test, the islets that had been exposed to heptanol during the first 15-min incubation (heptanol $3.5 \mathrm{mM}$ groups) were compared to islets that had been processed in parallel without ever being exposed to the alkanol (control groups). Values are mean \pm SEM of the numbers of islet batches indicated within parenthesis. ND, not determined.

${ }^{*} P<0.001$ as compared with the value observed in the glucose 2.8 mM group; ${ }^{\ddagger} P<0.001$ as compared with the value observed in the glucose $16.7 \mathrm{mM}$ group; ${ }^{\S} P<0.001$ as compared with the corresponding control group; " $P<0.05,{ }^{\text {" }} P<0.02,{ }^{* *} P<0.005$, ${ }^{\text {\# }} P$ $<0.001$ as compared with the corresponding group of the first incubation.

with their neighbors. These changes were all reversible within 15 min after the removal of heptanol. At this time, B cell coupling was similar in islets that had been exposed to heptanol and then returned to a control medium (heptanol reversibility group) and in control islets that had not been exposed to the uncoupling agent (Table I).

Insulin secretion of primary $B$ cells. The insulin secretion of control and heptanol-exposed intact islets is shown both as absolute insulin output (Table II) and as percentage of the initial content of the B cells (Fig. 2). Both parameters show that in controls, insulin secretion was markedly $(P<0.001)$ stimulated over the basal value observed in the presence of 2.8 $\mathrm{mM}$ glucose, by both glucose $(16.7 \mathrm{mM})$ and glucose $(16.7$ $\mathrm{mM}$ ) plus IBMX (1 mM). Two changes of this normal pattern were seen during a 15-min incubation in the presence of a concentration of heptanol $(3.5 \mathrm{mM})$ causing cell uncoupling. First, basal secretion of insulin increased significantly $(P$ $<0.001)$. Secondly, both glucose and glucose plus IBMX did not anymore stimulate secretion over basal level (Table II and

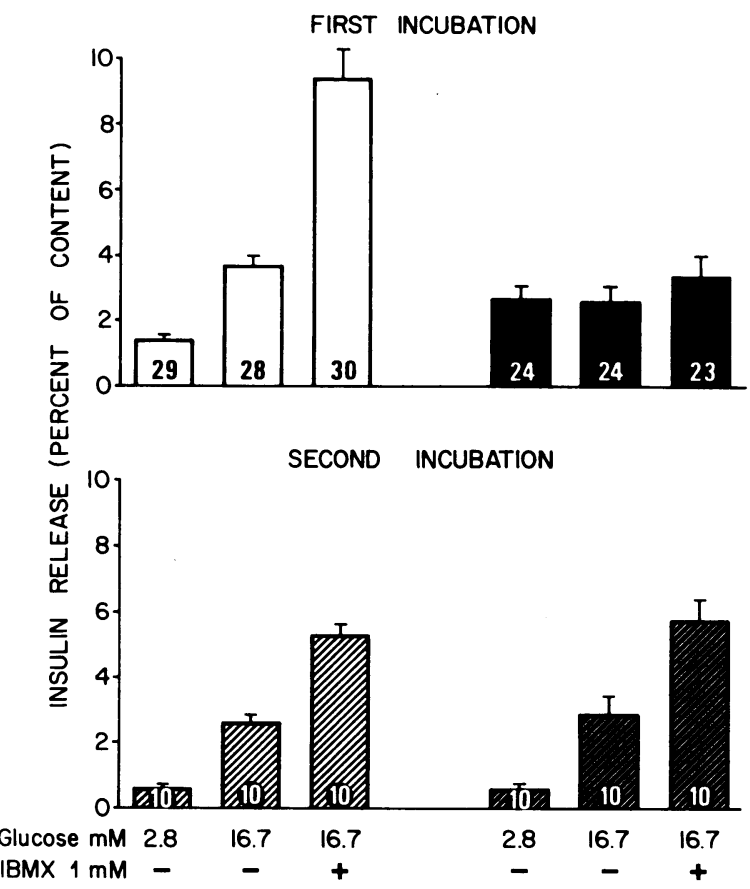

Figure 2. Insulin secretion of isolated rat islets during two successive 15 -min incubations at $37^{\circ} \mathrm{C}$. $(A)$ During the first incubation, the insulin secretion of control islets (open columns) was stimulated twofold by $16.7 \mathrm{mM}$ glucose and fivefold by addition of $1 \mathrm{mM}$ IBMX. Addition of $3.5 \mathrm{mM}$ heptanol (solid columns) increased significantly $(P<0.001)$ the basal secretion observed in the presence of $2.8 \mathrm{mM}$ glucose and abolished the stimulatory effect of both $16.7 \mathrm{mM}$ glucose and $16.7 \mathrm{mM}$ glucose plus $1 \mathrm{mM}$ IBMX. $(B)$ During the second 15-min incubation, which was performed after removal of heptanol, the secretion of islets that had been exposed to the uncoupler (dark shaded columns) was almost identical to that of controls that had been processed in parallel without being exposed to heptanol (light shaded columns). Insulin release was expressed as percentage of the initial hormone content of the islets. Values are mean \pm SEM of the number of islet batches indicated within the columns.

Fig. $2 A$ ). These two changes were fully reversible within 15 min after removal of the alcohol and return of the islets to a control medium (Table II and Fig. 2 B). Separate experiments showed a similar inhibition of secretagogue-induced release from isolated islets incubated for $15 \mathrm{~min}$ in the presence of a much lower concentration $(0.5 \mathrm{mM})$ of heptanol (Table II). Under the latter conditions, the islet output expressed as percentage of insulin content, represented $46.7 \%$ and $54.4 \%$ of the corresponding control value in the presence of $16.7 \mathrm{mM}$ glucose and $16.7 \mathrm{mM}$ glucose plus $1 \mathrm{mM}$ IBMX, respectively (not shown).

To assess whether the loss of B cell responsiveness to glucose could be due to the heptanol-induced B cell uncoupling, we further compared the effects of heptanol on the secretion of single (uncoupled) B cells and of B cell pairs, the smallest assemblies in which B cells can share gap junctions. ${ }^{2}$ Using a hemolytic plaque assay (Figs. 3 and 4), we found that, after a

2. Dual patch-clamp whole-cell recording and dye microinjection have indeed revealed the presence of junctional channels in some but not all pairs of $B$ cells $(19,20)$. The incidence of coupling in these small aggregates is consistent with the spatially restricted dye and electrical coupling observed within intact islets $(4,11,12,30)$. 

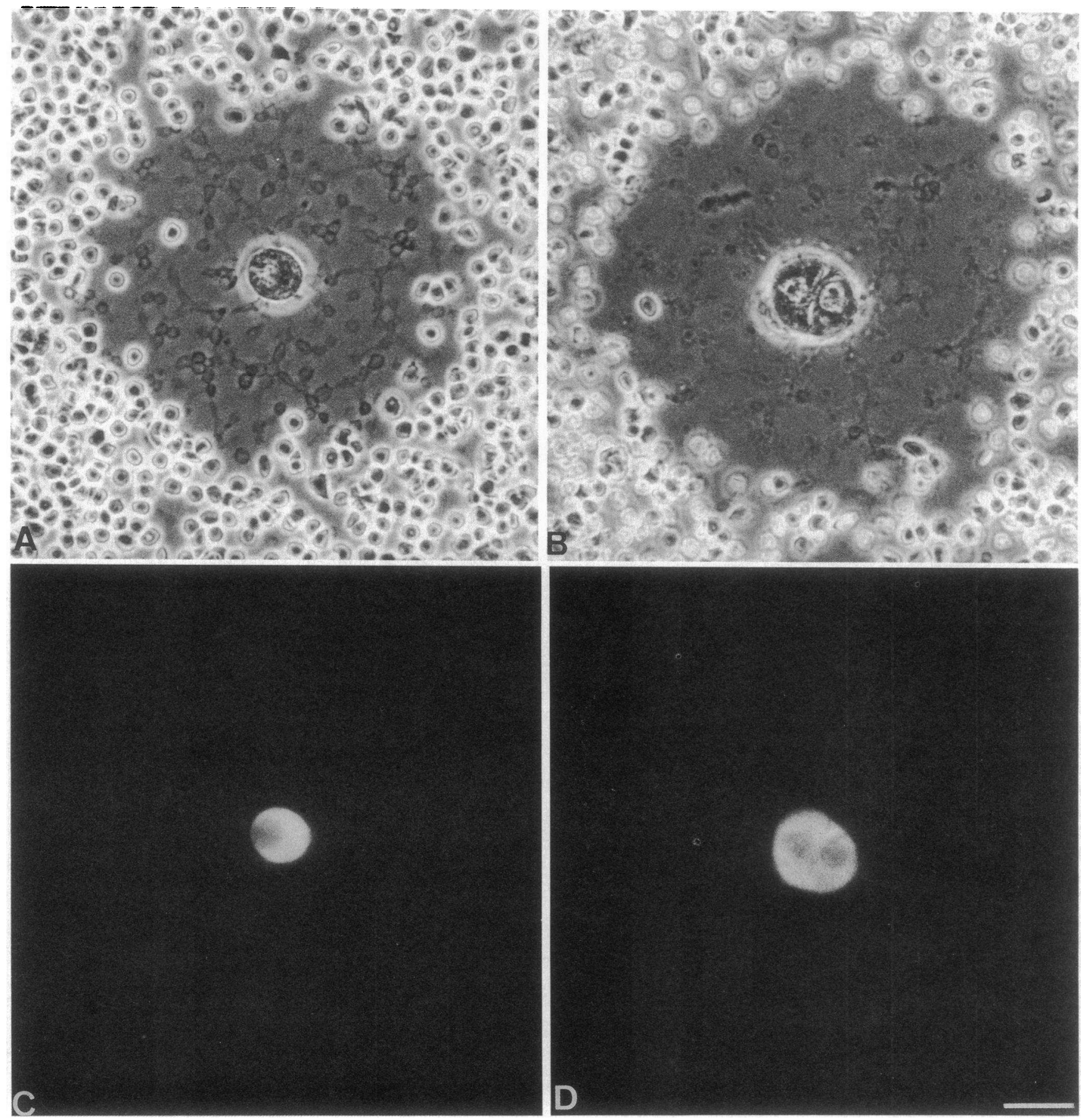

Figure 3. Phase-contrast and corresponding fluorescence views of dispersed islet cells studied in the hemolytic plaque assay for insulin. After a 30-min incubation in the presence of $16.7 \mathrm{mM}$ glucose and $0.5 \mathrm{mM}$ heptanol, single B cells $(A)$ and B cell pairs $(B)$ that secreted insulin are identified by a surrounding hemolytic plaque that comprises the nonrefringent ghosts of the complement-lysed erythrocytes. Immunostaining for insulin $(C$ and $D)$ revealed that, under the conditions of our test, all hemolytic plaques developed around differentiated insulin-containing B cells. Bar, $15 \mu \mathrm{m}$ in all panels.

30 -min stimulation by $16.7 \mathrm{mM}$ glucose, $48.8 \pm 3.9 \%$ of single B cells had formed a hemolytic plaque ${ }^{3}$ with an area of

3. This percentage was 9.2 time higher $(P<0.001)$ than that of single $B$ cells releasing detectable amounts of insulin in the presence of $2.8 \mathrm{mM}$ glucose (Table III), indicating that dispersed B cells had retained responsiveness to their physiological secretagogue.
$1,368 \pm 117 \mu \mathrm{m}^{2}$ (Table III). These values were significantly ( $P$ $<0.001$ ) lower than those evaluated for B cell pairs (Table III). As a result, total plaque development (the product of the proportion of plaque-forming cells by the area of individual hemolytic plaques) of $\mathrm{B}$ cell pairs was three- to fourfold higher ( $P$ $<0.001$ ) than that of single B cells (Fig. $4 \mathrm{~A}$ ). Correcting for the different numbers of $B$ cells that account for this higher figure, 

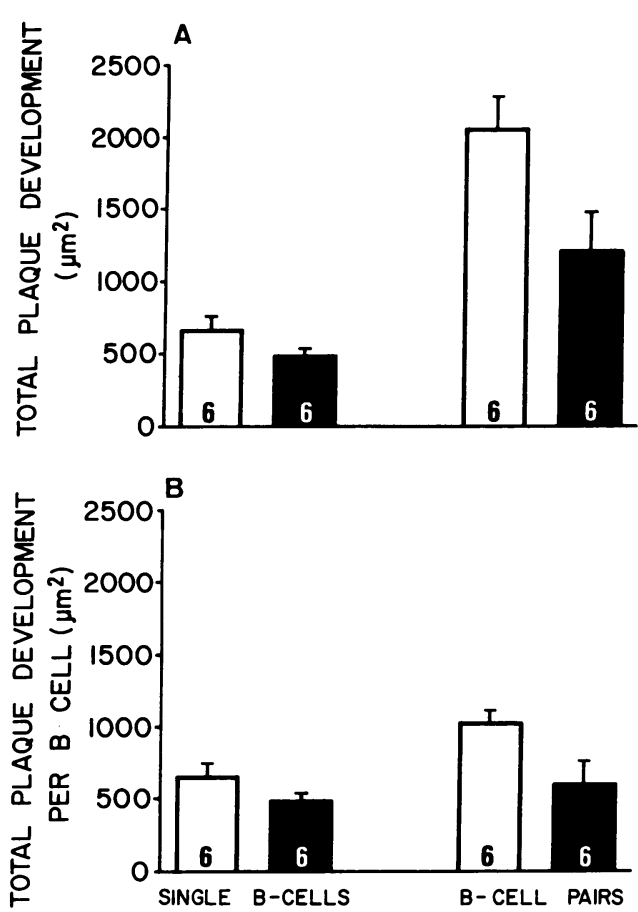

Figure 4. Total development of hemolytic plaques reflecting the insulin secretion of single B cells and B cell pairs after a 30-min incubation in the presence of $16.7 \mathrm{mM}$ glucose (open columns) and 16.7 $\mathrm{mM}$ glucose plus $0.5 \mathrm{mM}$ heptanol (solid columns). (A) Under control conditions (open columns), total plaque development was 3.1 times higher $(P<0.001)$ for B cell pairs $\left(2059 \pm 197 \mu \mathrm{m}^{2}, n=6\right)$ than for single B cells $\left(661 \pm 72 \mu \mathrm{m}^{2}, n=6\right)$. Addition of heptanol (solid columns) did not modify significantly the total plaque development of single B cells $\left(488 \pm 43 \mu \mathrm{m}^{2}, n=6\right)$ but markedly decreased $(P$ $<0.02)$ that of B cell pairs $\left(1213 \pm 251 \mu \mathrm{m}^{2}, n=6\right)$. (B) Expression of these data on a per cell basis resulted in a total plaque development which, under control conditions (open columns), was higher $(P$ $<0.01)$ for a B cell within a pair $\left(1,029 \pm 99 \mu \mathrm{m}^{2}, n=6\right)$ than for a single B cell $\left(661 \pm 72 \mu \mathrm{m}^{2}, n=6\right)$. As the size of a hemolytic plaque is a function of the amount of hormone secreted, these data indicate that the average output of control individual $B$ cells was about twice as high when a B cell was part of a pair than when it occurred as a single cell. This difference was no more evident in the presence of heptanol (solid columns), owing to a significant reduction $(P<0.02)$ of plaque development estimated for the individual $B$ cells that formed pairs $\left(606 \pm 125 \mu \mathrm{m}^{2}, n=6\right)$.

we found that total plaque development per cell (the ratio of total plaque development by the number of $B$ cells) was, in average, about twice as large $(P<0.01)$ for $B$ cell pairs than for single B cells (Fig. $4 \mathrm{~B}$ ). Addition of $0.5 \mathrm{mM}$ heptanol did not affect significantly the proportion of single $B$ cells that were glucose-responsive and the area of the hemolytic plaques they formed (Table III). By contrast, these parameters were significantly $(P<0.02-0.05)$ reduced in B cell pairs (Table III), leading to a marked reduction $(P<0.02)$ of total plaque development (Fig. $4 A$ ). As a result, even though this parameter was still significantly $(P<0.02)$ higher for B cell pairs than for single B cells (Fig. $4 A$ ), total plaque development per cell was now similar whether B cells were part of pairs or occurred as single units (Fig. $4 \mathrm{~B}$ ). Comparable results were obtained in the presence of $3.5 \mathrm{mM}$ heptanol, even though in the presence of this alkanol concentration, the proportion of single B cells stained by trypan blue was increased (not shown).
Table III. Parameters Characterizing Primary B Cells in the Plaque Assay for Insulin

\begin{tabular}{|c|c|c|c|}
\hline $\begin{array}{c}\text { Cell } \\
\text { arrangement }\end{array}$ & Group & $\begin{array}{l}\text { Plaque-forming } \\
\text { aggregates }\end{array}$ & $\begin{array}{l}\text { Individual } \\
\text { plaque area }\end{array}$ \\
\hline & & $\%$ & $\mu m^{2}$ \\
\hline \multirow[t]{6}{*}{ Single B cells } & Glucose $2.8 \mathrm{mM}$ & $5.3 \pm 1.0$ & $937 \pm 213$ \\
\hline & & $(32 / 6)$ & $(32 / 6)$ \\
\hline & Glucose $16.7 \mathrm{mM}$ & $48.8 \pm 3.9^{*}$ & $1,368 \pm 117$ \\
\hline & & $(1331 / 6)$ & $(655 / 6)$ \\
\hline & Glucose $16.7 \mathrm{mM}$ & $42.2 \pm 2.8^{*}$ & $1,162 \pm 80$ \\
\hline & + heptanol $0.5 \mathrm{mM}$ & $(989 / 6)$ & $(427 / 6)$ \\
\hline \multirow[t]{6}{*}{ B cell pairs } & Glucose $2.8 \mathrm{mM}$ & $5.7 \pm 1.8$ & $1,061 \pm 190$ \\
\hline & & $(11 / 6)$ & $(11 / 5)$ \\
\hline & Glucose $16.7 \mathrm{mM}$ & $83.0 \pm 2.9^{* \neq \ddagger}$ & $2,467 \pm 208^{* \neq \ddagger}$ \\
\hline & & $(370 / 6)$ & $(305 / 6)$ \\
\hline & Glucose $16.7 \mathrm{mM}$ & $66.1 \pm 5.4^{* \ddagger * *}$ & $1,761 \pm 249^{\S}$ \\
\hline & + heptanol $0.5 \mathrm{mM}$ & $(241 / 6)$ & $(166 / 6)$ \\
\hline
\end{tabular}

Numbers in parentheses are number of single cells and cell pairs/ number of experiments scored (for the percentage of plaque-forming aggregates parameter) and number of hemolytic plaques/number of experiments scored (for the individual plaque area parameter). * $P<0.01$ as compared with the values found in the glucose $2.8 \mathrm{mM}$ group; ${ }^{\ddagger} P<0.02$ as compared with the values found in the glucose

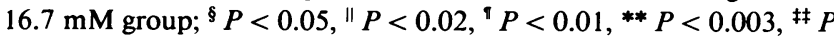
$<0.001$ as compared with the corresponding values of single $B$ cells.

Coupling and secretion of RINm5F cells. To assess further whether heptanol had pleiotropic, nonspecific effects on various steps of the secretory machinery, we used the RINm5F line which is a convenience source of well-characterized insulin-secreting cells.

Under control conditions, microinjection experiments revealed that $54 \%$ of the RIN cells exchanged Lucifer yellow with a limited number $(1.7 \pm 0.1)$ of companion cells. As with primary B cells, the percentage was significantly $(P<0.015)$ reduced after a few minutes of exposure to $3.5 \mathrm{mM}$ heptanol, a condition under which about $61 \%$ of RIN cells were dye uncoupled (Fig. 5 and Table IV). RIN cells recovered a control level of dye coupling shortly after heptanol was removed and the cultures were returned to control medium (Table IV).

Table IV. Extent of Coupling between RINm5F Cells

\begin{tabular}{lcc}
\hline \multicolumn{1}{c}{ Group } & $\begin{array}{c}\text { Dye-labeled } \\
\text { RIN cells* }\end{array}$ & $\begin{array}{c}\text { Uncoupled } \\
\text { RIN cells }\end{array}$ \\
Control & $n$ & $\%$ \\
Heptanol $3.5 \mathrm{mM}$ & $1.8 \pm 0.1$ & 46 \\
Heptanol reversibility & $(41)$ & 61 \\
& $1.4 \pm 0.1^{\ddagger}$ & 47 \\
& $(49)$ & \\
\hline
\end{tabular}

Values are mean \pm SEM and were compared using the unpaired Student's $t$ test. * The number of microinjected clusters which were scored is indicated in parentheses. ${ }^{\ddagger} P<0.015$ as compared with the corresponding control group; ${ }^{\S} P<0.017$ as compared with the heptanol group. 

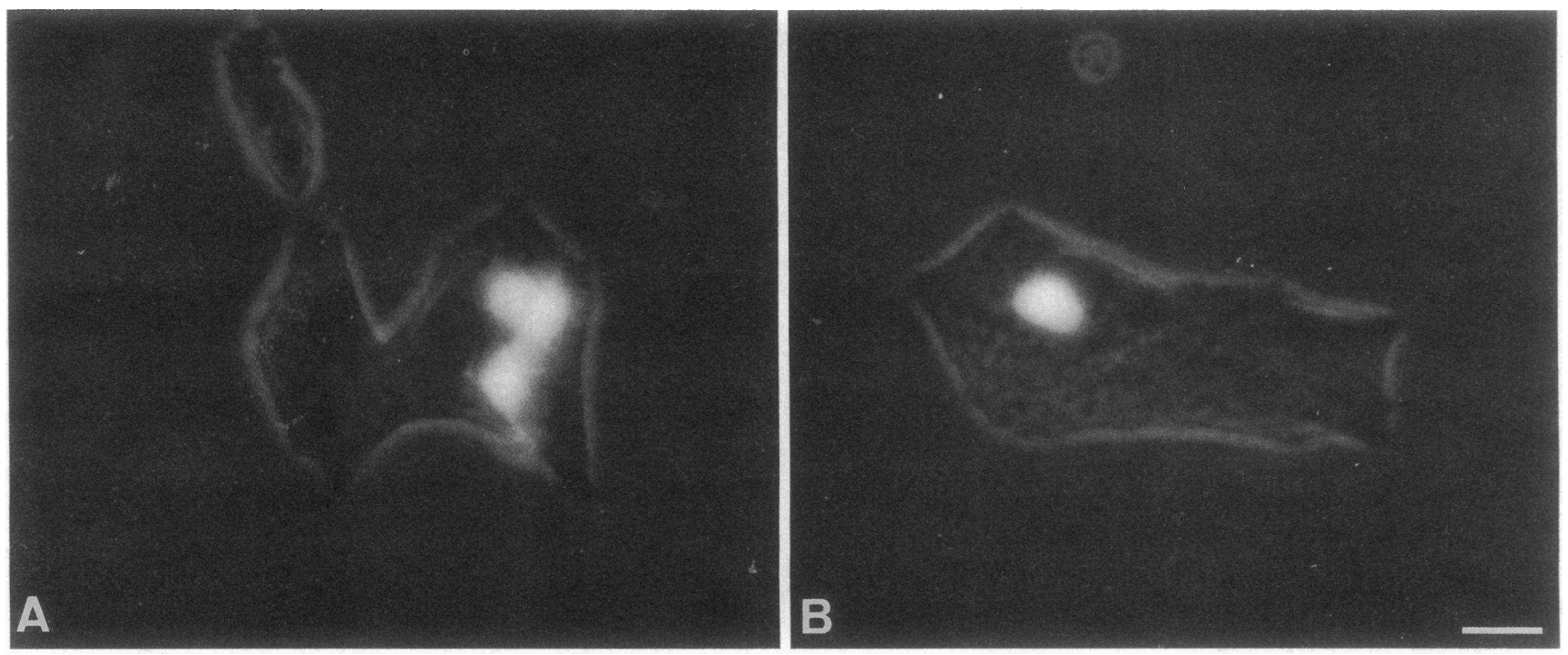

Figure 5. Clusters of RINm5F cells microinjected with Lucifer yellow. $(A)$ In a control cluster, the tracer was exchanged between three adjacent cells, revealing junctional coupling. $(B)$ In a cluster exposed for $5 \mathrm{~min}$ to $3.5 \mathrm{mM}$ heptanol, Lucifer yellow remained within the injected cell, revealing uncoupling of this cell from its neighbors. Bar, $20 \mu \mathrm{m}$ in both panels.

In terms of insulin secretion, RIN cells, as primary B cells, responded more to secretagogue stimulation when they were aggregated than when they were single (uncoupled). In the presence of D-glyceraldehyde, ${ }^{4}$ the increment above basal secretion was 4.2- and 1.9-fold in these two groups, respectively (Table V and Fig. 6). Furthermore, again as with primary B cells, heptanol markedly inhibited $(P<0.01)$ the secreta-

4. This secretagogue, that mimics the effect of glucose on normal B cell secretion, was chosen because RINm5F cells are unresponsive to Dglucose (21). gogue-stimulated secretion of aggregated RIN cells, but had no significant effect on the corresponding secretion of single RIN cells (Table V and Fig. 6).

To assess whether heptanol perturbed the most distal steps of secretion, single RINm5F cells were electropermeabilized and then assessed for insulin release in the presence of different $\mathrm{Ca}^{2+}$ concentrations. In this system, an increase in $\mathrm{Ca}^{2+}$ concentration from $10^{-7}$ to $10^{-5} \mathrm{M}$, elicited a three- to sevenfold increase $(P<0.01)$ in insulin release (Table $\mathrm{V}$ and Fig. 7 ). Addition of $3.5 \mathrm{mM}$ heptanol did not modify the basal insulin release observed in the presence of $10^{-7} \mathrm{M} \mathrm{Ca}^{2+}$ nor did it

Table V. Insulin Secretion of RINm5F Cells

\begin{tabular}{|c|c|c|c|}
\hline \multirow[b]{2}{*}{ Cell arrangement } & \multirow[b]{2}{*}{ Group } & \multicolumn{2}{|c|}{ Immunoreactive insulin } \\
\hline & & Control & Heptanol $3.5 \mathrm{mM}$ \\
\hline & & \multicolumn{2}{|c|}{ ng/sample per $30 \mathrm{~min}$} \\
\hline \multirow[t]{2}{*}{ Intact single cells } & Glucose $2.8 \mathrm{mM}$ & $\begin{array}{l}20.2 \pm 3.9 \\
\quad(15)\end{array}$ & $\begin{array}{c}19.7 \pm 1.0 \\
(15)\end{array}$ \\
\hline & Glucose $2.8 \mathrm{mM}+$ D-glyceraldehyde $10 \mathrm{mM}$ & $\begin{array}{c}38.0 \pm 3.5^{*} \\
\quad(15)\end{array}$ & $\begin{array}{r}35.1 \pm 1.6^{\ddagger} \\
(15)\end{array}$ \\
\hline \multirow[t]{2}{*}{ Intact aggregated cells } & Glucose $2.8 \mathrm{mM}$ & $\begin{array}{l}49.4 \pm 4.6 \\
\quad(15)\end{array}$ & $\begin{array}{r}37.7 \pm 2.2^{\S} \\
(15)\end{array}$ \\
\hline & Glucose $2.8 \mathrm{mM}+$ D-glyceraldehyde $10 \mathrm{mM}$ & $\begin{array}{c}208.7 \pm 8.3^{\ddagger} \\
(15)\end{array}$ & $\begin{array}{c}70.8 \pm 5.2^{\ddagger \pi} \\
(15)\end{array}$ \\
\hline \multirow[t]{2}{*}{ Permeabilized single cells } & $10^{-7} \mathrm{M} \mathrm{Ca}^{2+}$ & $\begin{array}{c}3.4 \pm 0.2 \\
(9)\end{array}$ & $\begin{array}{r}4.2 \pm 0.2^{\ddagger} \\
(9)\end{array}$ \\
\hline & $10^{-5} \mathrm{M} \mathrm{Ca}^{2+}$ & $\begin{array}{l}12.8 \pm 2.0^{* *} \\
\quad(9)\end{array}$ & $\begin{array}{c}14.4 \pm 2.3^{* *} \\
(9)\end{array}$ \\
\hline
\end{tabular}

In the experiments on intact single cells, each tube contained 500,000 cells; in the experiments on intact aggregated cells, each dish contained about 2,500,000 cells; in the experiments on electropermeabilized cells, each tube contained 1,000,000 cells. The corresponding insulin contents (mean \pm SEM) were $362 \pm 13.4 \mathrm{ng} /$ tube $(n=60), 1979 \pm 59 \mathrm{ng} / \mathrm{dish}(n=60)$ and $215 \pm 14 \mathrm{ng} /$ tube $(n=36)$, respectively. ${ }^{*} P<0.005,{ }^{\ddagger} P$ $<0.001$ as compared with the value found in the glucose $2.8 \mathrm{mM}$ group; ${ }^{\S} P<0.005$, " $P<0.02, " P<0.001$ as compared with corresponding control group; ${ }^{* *} P<0.001$ as compared with the value found in the $10^{-7} \mathrm{Ca}^{2+}$ group. 


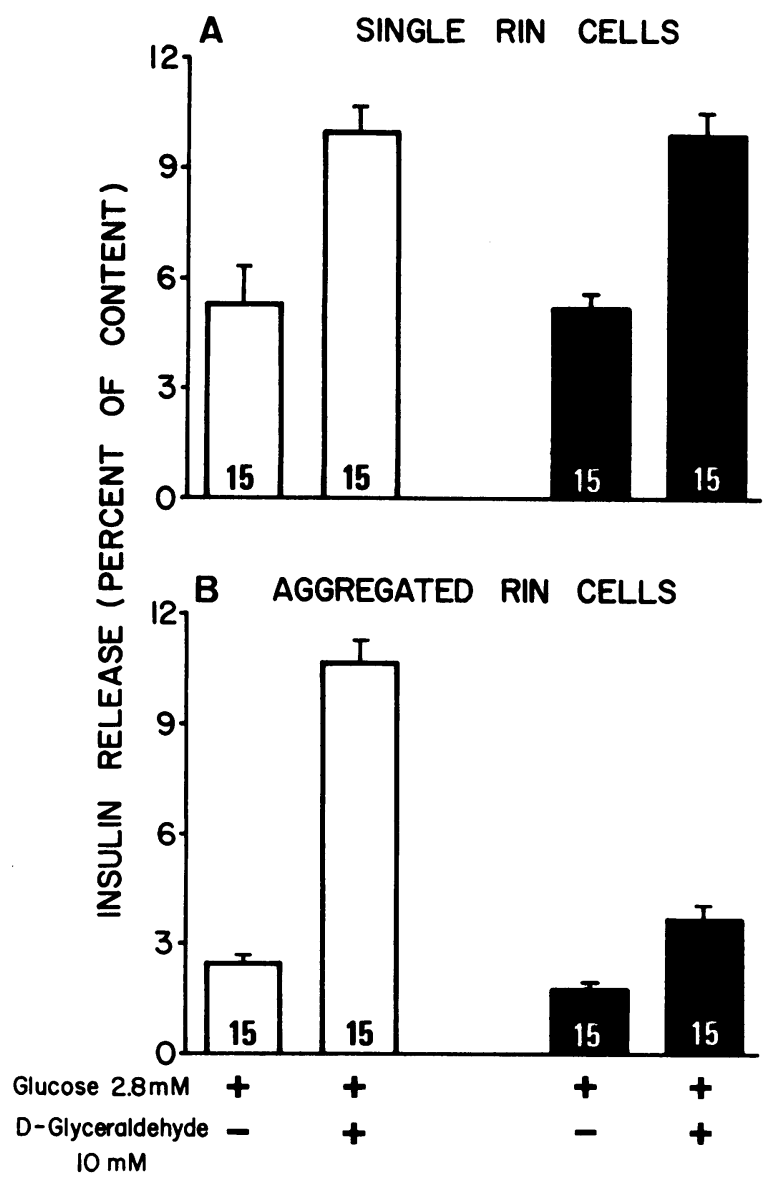

Figure 6. Insulin secretion of single and aggregated RINm5F cells. (A) Under control conditions (open columns), the insulin secretion of single cells increased 1.9 -fold $(P<0.005)$ during a 30 -min incubation in the presence of $10 \mathrm{mM}$ D-glyceraldehyde. Addition of 3.5 $\mathrm{mM}$ heptanol (solid columns) did not modify this glyceraldehyde-induced increase. $(B)$ Aggregated RIN cells were stimulated 4.3-fold ( $P$ $<0.001$ ) by D-glyceraldehyde. Addition of heptanol markedly decreased $(P<0.001)$ this normal glyceraldehyde-induced response. Insulin release was expressed as the percentage of the initial hormone content of the cells. Values are mean \pm SEM of the number of cell samples indicated within the columns.

affect the increased insulin output induced by $10^{-5} \mathrm{M} \mathrm{Ca}^{2+}$ (Table $\mathrm{V}$ and Fig. 7).

Cytosolic $\mathrm{Ca}^{2+}$ and $\mathrm{pH}$. As shown in Fig. 7, $3.5 \mathrm{mM}$ heptanol did not alter significantly the basal concentration $(145 \pm 16 \mathrm{nM}, n=7)$ of free $\mathrm{Ca}^{2+}\left(\left[\mathrm{Ca}^{2+}\right]_{\mathrm{i}}\right)$ in RINm5F cells loaded with fura- 2 and did not modify the extent $(98 \pm 9, n=7)$ and time course of the $\left[\mathrm{Ca}^{2+}\right]_{\mathrm{i}}$ increment caused by $10 \mathrm{mM}$ D-glyceraldehyde (Fig. 8, upper panel). In the presence of heptanol, these two parameters were $146 \pm 5 \mathrm{nM}(n=5)$ and $99 \pm 30 \mathrm{nM}(n=5)$, respectively.

Heptanol also did not alter basal intracellular $\mathrm{pH}\left(\mathrm{pH}_{\mathrm{i}}\right)$ in RINm5F cells loaded with BCECF $(7.11 \pm 0.03, n=4)$ and did not modify the decrease in $\mathrm{pH}_{\mathrm{i}}(0.09 \pm 0.01, n=5)$ induced by D-glyceraldehyde (Fig. 8, lower panel). In the presence of heptanol, these two parameters were $7.12 \pm 0.02(n=4)$ and $0.10 \pm 0.001(n=5)$, respectively. Similarly, heptanol did not alter the increase in $\mathrm{pH}_{\mathrm{i}}$ normally induced by $\mathrm{NH}_{4} \mathrm{Cl}$ (Fig. 8).

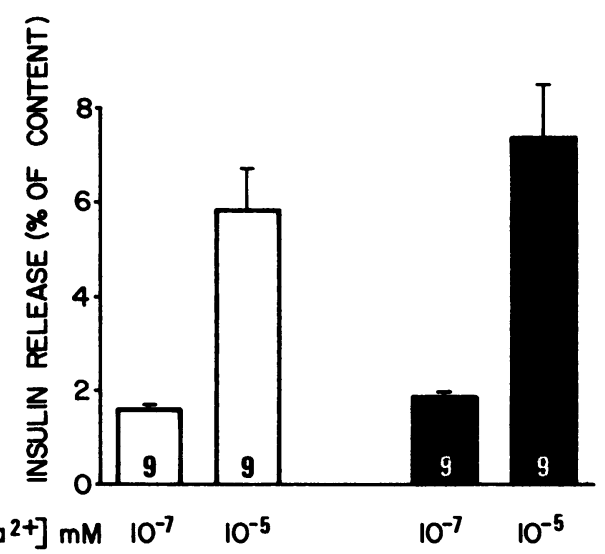

Figure 7. Insulin secretion of single electropermeabilized RINm5F cells. Under control conditions (open columns), raising the $\mathrm{Ca}^{2+}$ concentration of the incubation medium from $10^{-5}$ to $10^{-7} \mathrm{M}$ elicited a 3.7 -fold increase $(P<0.001)$ in the insulin secretion of RIN cells that had been electropermeabilized to permit the free access of the cation to cytoplasm. Addition of $3.5 \mathrm{mM}$ heptanol (solid columns), did not change this pattern significantly. Insulin release was expressed as percentage of the initial hormone content of the cells. Values are mean \pm SEM of the number of samples indicated within the columns.

\section{Discussion}

We have shown here that a long-chain alkanol that blocks gap junctions in several systems $(7,13,14,22-24)$, also uncouples B cells within intact pancreatic islets and affects in parallel their insulin secretion. Most strikingly, uncoupling concentrations of heptanol abolished within minutes the normal increase in insulin secretion caused by glucose. Both the coupling and the secretion changes were fully reversible within minutes after removal of heptanol and, thus, cannot be easily accounted for by a major toxic effect of the alcohol on B cells. Rather, the magnitude of these changes and their reversibility suggest that heptanol acts with some selectivity on one or more step(s) of the B cell secretory pathway that is (are) critical for a proper insulin secretion.

The obvious importance of unraveling the mechanism(s) whereby B cells may be, or become unresponsive to glucose under certain conditions $(6,8,15,25,26)$, led us to further investigate the rapid, marked, and fully reversible glucose unresponsiveness induced by heptanol. We first found that the heptanol effect was dependent on cell contact. Thus, in the presence of the alcohol, glucose-stimulated insulin secretion was not significantly modified in single B cells, but was markedly inhibited in B cell aggregates. The latter inhibition was already evident in pairs, the smallest assemblies in which two B cells can interact directly via gap junctions $(19,20)$. Whereas, under control conditions, the average secretory contribution of individual B cells was twice as high within pairs than when these cells were single, such a difference was no more observed in the presence of heptanol. Under the latter condition, B cells forming pairs secreted, individually, as if they were single cells.

The contact-dependent mechanism responsible for the heptanol-induced glucose unresponsiveness remains to be elucidated. The observation that heptanol blocks almost completely B cell gap junctions without disrupting the physical 


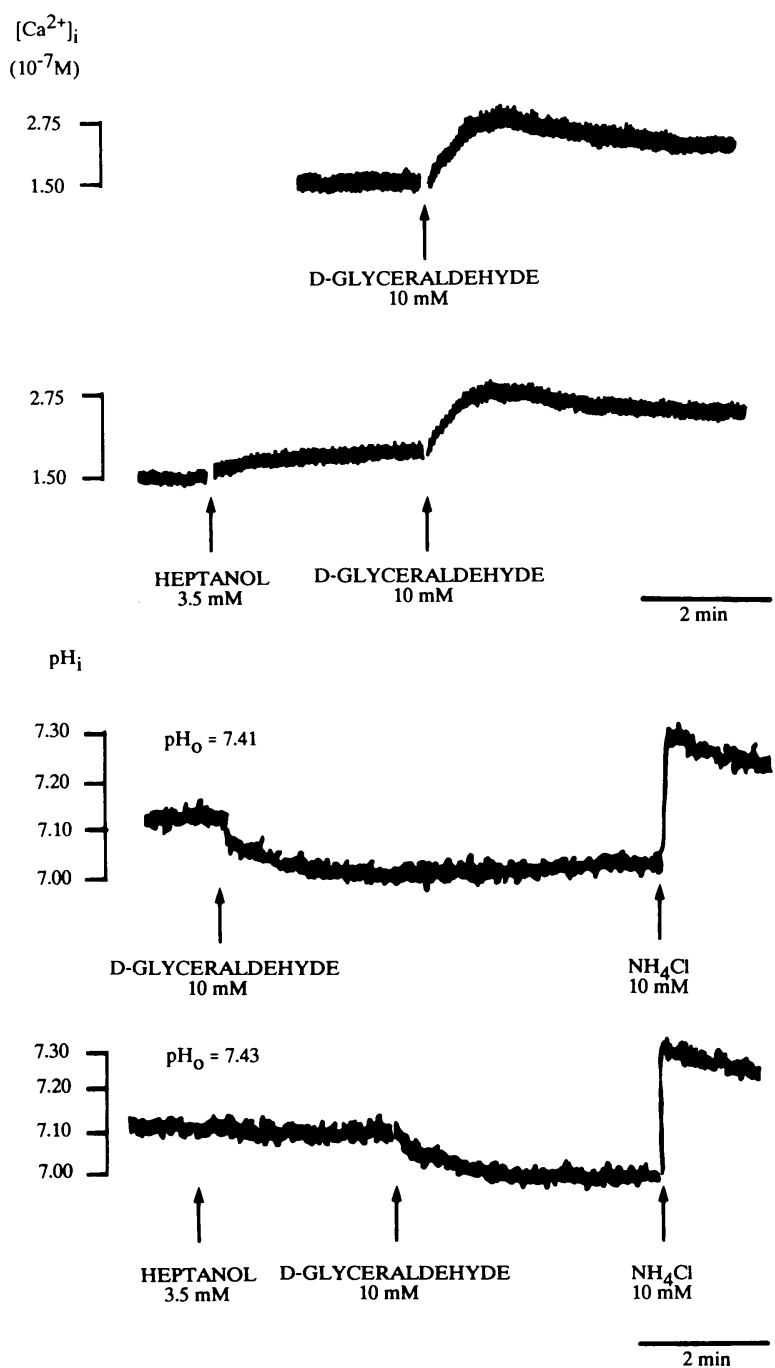

Figure 8. Cytosolic $\left[\mathrm{Ca}^{2+}\right]$ and pH of RINm5F cells. (Upper panel) The upper trace shows the normal increase of cytosolic free $\mathrm{Ca}^{2+}$ $\left(\left[\mathrm{Ca}^{2+}\right]_{\mathrm{i}}\right)$ caused by D-glyceraldehyde. The lower trace shows that 3.5 $\mathrm{mM}$ heptanol did not affect $\left[\mathrm{Ca}^{2+}\right]_{\mathrm{i}}$ significantly and did not modify the normal change of this parameter during a subsequent stimulation by D-glyceraldehyde. (Lower panel) The upper trace illustrates the normal changes of cytosolic $\mathrm{pH}\left(\mathrm{pH}_{\mathrm{i}}\right)$ in cells exposed to D-glyceraldehyde and to $\mathrm{NH}_{4} \mathrm{Cl}$. The lower trace shows that heptanol did not modify significantly these changes and basal $\mathrm{pH}_{\mathrm{i}}$. In both tracings, $\mathrm{pH}_{\mathrm{o}}$ is the $\mathrm{pH}$ of the extracellular medium that was monitored with a $\mathrm{pH}$ electrode.

integrity of intercellular contacts, favors the view that the secretory changes observed are somehow related to the inhibition of the direct cytoplasmic exchange of ions and small molecules that gap junction permit between adjacent $\mathrm{B}$ cells. Obviously, the alternative possibility that heptanol has pleiotropic effects which could perturb in parallel but independently the coupling and the secretion of B cells was considered. To test this possibility, we first studied whether heptanol affected the cytoplasmic free $\mathrm{Ca}^{2+}$ and $\mathrm{pH}$ of insulin-producing cells, since these two factors are thought to be implicated in the physiological blockade of gap junctions $(2,3,27)$ and are known to also influence several steps of insulin secretion $(28,29)$. Since in- tracellular $\mathrm{Ca}^{2+}$ and $\mathrm{pH}$ measurements are not readily carried out on intact islets and require large numbers of dispersed cells, we used, as a model, cells of the RIN line (9). When compared to primary B cells under control (basal or stimulated) conditions, the RIN cells we used showed a less frequent and extensive coupling and secreted much less insulin. In spite of these quantitative differences, the patterns of RIN cell coupling and secretion showed the major features observed with primary B cells. Thus coupling, as revealed by the exchange of Lucifer yellow, was not a consistent feature of every RIN cell and, when it occurred, it never involved the entire cell population comprising a culture cluster. Furthermore, insulin secretion was two to five times larger from aggregated than from single RIN cells, a pattern also observed with primary B cells. After exposure to heptanol, the behavior of RIN cells was also reminiscent of that of B cells. Thus, RIN cells also uncoupled in a rapid and fully reversible way and became unresponsive to D-glyceraldehyde, a secretagogue that mimics the effects of glucose on islet function, in a manner which, as for primary B cells, depended on cell contact. Thus, in spite of some differences, for example as far as the effect of heptanol on basal insulin secretion was concerned, RIN cells represented an acceptable model system in the context of our experiments. Using these cells, we found that concentrations of heptanol causing uncoupling and inhibiting the glyceraldehyde-induced increase in insulin release, did not cause detectable alterations of either cytosolic $\left[\mathrm{Ca}^{2+}\right]$ or $\mathrm{pH}$ of RIN cells, suggesting that these two factors most likely did not mediate the changes in both coupling and secretion. Even though RIN cells differ in several respects from primary $B$ cells, previous reports have shown that these two cell types handle similarly their intracellular $\mathrm{Ca}^{2+}$ and $\mathrm{pH}$ under a variety of other experimental conditions (21), thus favoring the view that they will not behave differently in the presence of heptanol. As a second approach to further investigate possible, nonspecific effects of heptanol, we assessed whether the alcohol perturbed the most distal steps of the secretory machinery that lead to the fusion of secretory granules with the plasma membrane. The observation that uncoupling concentrations of heptanol did not modify the $\mathrm{Ca}^{2+}$-induced secretion of single electropermeabilized RIN cells did not provide evidence for such a perturbation. In summary, the unchanged intracellular $\mathrm{Ca}^{2+}$, intracellular $\mathrm{pH}$ and $\mathrm{Ca}^{2+}$-induced insulin release, together with the lack of effect of heptanol on the secretion of single cells, strongly indicate that, even if the alcohol alters B cell organelles (30) and channels ${ }^{5}$ other than gap junctions, such an effect alone could most unlikely explain the secretory changes we observed in aggregated cells.

In summary, the present data provide several lines of evidence that the rapid loss of responsiveness to secretagogues observed after exposure of aggregated insulin-producing cells to heptanol was most likely related to the alcohol-induced blockade of B cell gap junctions. Control of secretion by gap junction-mediated cell-to-cell communication has been sug-

5. Using the whole-cell configuration of the patch-clamp technique, we have found that, occasionally, heptanol inhibits partially the outward currents recorded in single B cells (M. Chanson and P. Meda, unpublished observations). 
gested as a possible mechanism coordinating the functioning of the numerous secretory cells that form most vertebrate glands $(3,4,13,14,24,32)$. The experiments we report here provide the novel evidence that short-term and fully reversible changes in junctional coupling are paralleled by drastic and rapid changes in insulin secretion from intact pancreatic islets and insulin-producing cells in contact. The abolished secretagogue-induced stimulation of insulin release seen during B cell uncoupling is in marked contrast with the secretion change which is associated with the uncoupling of the acinar cells of the exocrine pancreas $(13,14,24,31)$. In this gland, that differs markedly from the islets of Langerhans in several respects, including the composition and amount of gap junctions, the resting organization of intercellular communications and their modulation during secretagogue challenge (32), heptanol causes a rapid, marked and fully reversible increase in amylase secretion $(13,14,24)$. Although the reason(s) for this opposite behavior remain(s) to be elucidated, the different secretory change of endocrine and exocrine cells uncoupled by heptanol argues further against a generalized, nonspecific cell perturbation induced by the alkanol. Rather, the data imply a more subtle, tissue-specific effect of this agent, likely related to the inhibition of the gap junction-mediated cell-to-cell communications it causes.

\section{Acknowledgments}

We thank L. Burkhardt, A. Charollais, S. De Mitri, P. Ruga, J.-P. Gerber, and C. Bartley for technical assistance.

This work was supported by grant 31-26625.89 from the Swiss National Science Foundation and grant 187384 from the Juvenile Diabetes Foundation International.

\section{References}

1. Orci, L., R. H. Unger, and A. E. Renold. 1973. Structural coupling between pancreatic islet cell. Experientia (Basel). 29:1015-1018.

2. Loewenstein, W. R. 1981. Junctional intercellular communication: the cell-to-cell membrane channel. Physiol. Rev. 61:829-913.

3. Hertzberg, E. L., and R. G. Johnson, editors. 1988. Gap Junctions. Alan R. Liss, Inc., New York. 548 pp.

4. Meda, P., A. Perrelet, and L. Orci. 1984. Gap junctions and cell-to-cell coupling in endocrine glands. Mod. Cell Biol. 3:131-196.

5. Meda, P., A. Perrelet, and L. Orci. 1979. Increase of gap junctions between pancreatic B-cells during stimulation of insulin secretion. J. Cell Biol. 82:441-448.

6. Halban, P. A., C. B. Wollheim, B. Blondel, P. Meda, E. N. Niesor, and D. N. Mintz. 1982. The possible importance of contact between pancreatic islet cells for the control of insulin release. Endocrinology. 111:86-94.

7. Johnston, M. F., S. A. Simon, and F. Ramon. 1980. Interaction of anaesthetics with electrical synapses. Nature (Lond.). 286:498-500.

8. Salomon, D., and P. Meda. 1986. Heterogeneity and contactdependent regulation of hormone secretion by individual B-cells. Exp. Cell Res. 162:507-520.

9. Gazdar, A. F., W. L. Chick, H. K. Oie, H. L. Sims, D. L. King, G. C. Weir, and V. Lauris. 1980. Continuous, clonal, insulin- and somatostatin-secreting cell lines established from a transplantable rat islet cell tumor. Proc. Natl. Acad. Sci. USA. 77:3519-3523.

10. Vallar, L., T. J. Biden, and C. B. Wollheim. 1987. Guanine nucleotides induce $\mathrm{Ca}^{2+}$-independent insulin secretion from permeabilized RINm5F cells. J. Biol. Chem. 262:5049-5056.

11. Meda, P., R. L. Michaels, P. A. Halban, L. Orci, and J. D.
Sheridan. 1983. In vivo modulation of gap junctions and dye coupling between B-cells of the intact pancreatic islet. Diabetes. 32:858-868.

12. Meda, P., R. M. Santos, and I. Atwater. 1986. Direct identification of electrophysiologically monitored cells within intact mouse islets of Langerhans. Diabetes. 35:232-235.

13. Meda, P., R. Bruzzone, S. Knodel, and L. Orci. 1986. Blockage of cell-to-cell communication within pancreatic acini is associated with increased basal release of amylase. J. Cell Biol. 103:475-483.

14. Meda, P., R. Bruzzone, M. Chanson, D. Bosco, and L. Orci. 1987. Gap junctional coupling modulates secretion of exocrine pancreas. Proc. Natl. Acad. Sci. USA. 84:4901-4904.

15. Bosco, D., L. Orci, and P. Meda. 1989. Homologous but not heterologous contact increases the insulin secretion of individual pancreatic B-cells. Exp. Cell Res. 184:72-80.

16. Jerne, N. K., C. Henry, A. A. Nordin, H. Fuji, A. M. C. Koros, and I. Lefkovits. 1974. Plaque forming cells: methodology and theory. Transplant. Rev. 18:130-191.

17. Alberts, W., A. Wouters, D. Van der Massen, A. Persoons, and C. Denef. 1988. A diffusion-adsorption model for the computation of the amount of hormone around a secreting cell, detected by the reverse hemolytic plaque assay. J. Theor. Biol. 131:441-459.

18. Wollheim, C. B., and T. J. Biden. 1986. Second messenger function of inositol 1,4,5-trisphosphate. J. Biol. Chem. 261:83148319.

19. Perez-Armendariz, E. M., D. C. Spray, and M. V. L. Bennett. 1988. Properties of gap junctions between pairs of pancreatic beta cells of mice. Biophys. J. 53:53a. (Abstr.)

20. Meda, P., D. Bosco, E. Giordano, and M. Chanson. In Biophysics of Gap Junction Channels. C. Peracchia, editor. CRC Press, Boca Raton, FL. In press.

21. Wollheim, C. B., and T. J. Biden. 1986. Signal transduction in insulin secretion: comparison between fuel stimuli and receptor agonists. Ann. NY Acad. Sci. 488:317-333.

22. Bernardini, G., C. Peracchia, and L. L. Peracchia. 1984. Reversible effects of heptanol on gap junction morphology in mammalian heart. J. Membr. Biol. 34:307-312.

23. Délèze, J., and J. C. Hervé. 1983. Effect of several uncouplers of cell-to-cell communication on gap junction morphology in mammalian heart. J. Membr. Biol. 74:203-215.

24. Chanson, M., R. Bruzzone, D. Bosco, and P. Meda. 1989. Effects of $\mathrm{n}$-alcohols on junctional coupling and amylase secretion of pancreatic acinar cells. J. Cell. Physiol. 139:147-156.

25. Cerasi, E., R. Luft, and S. Efendic. 1971. Decreased sensitivity of pancreatic beta cells to glucose in prediabetic and diabetic subjects: a glucose dose-response study. Diabetes 21:224-234.

26. Bonner-Weir, S., D. F. Trent, R. N. Honey, and G. C. Weir. 1981. Responses of neonatal rat islets to streptozotocin. Limited B-cell regeneration and hyperglycemia. Diabetes. 30:64-69.

27. Spray, D. C., and L. V. Bennet. 1985. Physiology and pharmacology of gap junctions. Ann. Rev. Physiol. 47:281-303.

28. Prentki, M., and F. M. Matschinsky. 1987. $\mathrm{Ca}^{2+}$, cAMP, and phospholipid-derived messengers in coupling mechanisms of insulin secretion. Physiol. Rev. 67:1185-1248.

29. Pace, C. S., J. T. Tarvin, and J. S. Smith. 1983. Stimulus-secretion coupling in B-cells: modulation by pH. Am. J. Physiol. 244:E3E18.

30. Knodel, S., P. Meda, and L. Orci. 1987. Rapid in vitro formation of smooth endoplasmic reticulum aggregates within peptide-producing islet cells. J. Cell. Physiol. 133:111-118.

31. Bruzzone, R., and P. Meda. 1988. The gap junction: a channel for multiple functions? Eur. J. Clin. Invest. 18:444-453.

32. Meda, P. Gap junctional coupling and secretion in endocrine and exocrine pancreas. 1989. Cell interactions and gap junctions. In Cell Interactions and Gap Junctions, Vol. I. N. Sperelakis and W. C. Cole, editors. CRC Press, Boca Raton, FL. 59-79. 